IBIS I 3 I : $578-588$

\title{
Breeding season, courtship behaviour, and territoriality of White and Japanese Wagtails Motacilla alba and M. grandis
}

\author{
HIROYOSHI HIGUCHI* $₫ \&$ TOSHIAKI HIRANO \\ * Laboratory of Forest Zoology, Faculty of Agriculture, The University of Tokyo, \\ Tokyo 113, Japan and Museum of Zoology, The University of Michigan, Ann \\ Arbor, Michigan 48109, USA and †c/o Tomuro, Yoshino 2-3-15, Utsunomiya, \\ Tochigi 320, Yapan
}

Accepted 15 August 1988

\begin{abstract}
The breeding ecology of White and Japanese Wagtails, Motacilla alba and M. grandis, was studied along a river in central Japan. The home ranges of the two species greatly overlapped along the river, but no interbreeding occurred. $\boldsymbol{M}$. grandis spent more time on the river than $\boldsymbol{M}$. alba and defended territories there. $M$. alba used the river as part of the entire home range, and did not defend the river areas as territories. Singing activity and breeding started earlier in $M$. grandis than in $M$. alba. The early breeding of $M$. grandis was related to the lack of moulting in spring, less necessity for pair formation due to the existence of pairs in the winter, and the greater dependency on larval than on adult insects. Songs were very different between the two species. The bowing display that preceded the pre-copulation display was found only in $M$. alba. During the pre-copulation display, male $M$. grandis lifted both wings above the horizontal while male $M$. alba drooped both wings. The pre-copulation display of $M$. grandis was similar to that of Large Pied Wagtails $M$. maderaspatensis in India, suggesting a closer relationship of the two species than to $M$. alba.
\end{abstract}

The Japanese Wagtail Motacilla grandis is endemic to Japan and is thought to have differentiated in geologically recent times from the continental White Wagtail $M$. alba through geographic isolation (Mayr 1963). However, Japanese Wagtails are very similar in appearance to the Large Pied Wagtail $M$. maderaspatensis in India. This similarity suggests that Japanese Wagtails may be more closely related to Large Pied Wagtails than to White Wagtails, and that the present distribution of the former two species may be a relic of the past extensive distribution of their common ancestor (Nakamura 1985, Higuchi 1987). At present there is insufficient data to show which of these two hypotheses is more reasonable.

In Japan, until the early 1970 s the breeding ranges of White and Japanese Wagtails were generally separate but overlapped locally in the northern and southern main islands. Recently, however, the northern $(M$. a. lugens) and the southern (M. a. leucopsis) populations of White Wagtails have expanded their breeding areas into central Japan (Nakamura 1978, Higuchi \& Hirano 1981), thereby increasing sympatry with $M$. grandis.

Stepanyan $(1978,1983)$ treated $M$. a. lugens as a separate species $M$. lugens because that form and other $M$. alba subspecies are sympatric with limited hybridization in Kamchatka and southern Ussuriland. However, in Japan, M. a. lugens and $M$. a. leucopsis interbreed in some places (e.g. Okayama 1984).

† Present address: Wild Bird Society of Japan, Higashi 2-24-5, Shibuya-Ku, Tokyo 150, Japan. 
Therefore, for the time being, we treat lugens as a subspecies of $M$. alba. M.grandis, on the other hand, was treated as a subspecies of $M$. alba by Chen (1973b). However, $M$. grandis and $M$. alba are almost completely reproductively isolated in Japan (Higuchi \& Hirano 1983b, Higuchi 1984), though some questionable accounts of interbreeding have been reported (e.g. Nakamura \& Iwamoto 1985, Koshihara 1983). In this paper we treat grandis as a separate species, and discuss the reproductive isolation between them.

We have investigated the comparative ecology of $M$. alba lugens and $M$.grandis in a river of central Japan, where the two forms occur in similar abundance (Higuchi \& Hirano 1981, 1983a, b, Hirano \& Higuchi 1986). In this paper we describe the habitat use, territoriality, breeding season, songs and singing activity, courtship display, and feeding habits of the two species, greatly amplifying the earlier study of Nakamura et al. (1984).

\section{Study area and methods}

Observations were made from January to August in 1982-1984 along a 2-km stretch of the Tagawa River in Utsunomiya, central Honshu, the same area described in Higuchi \& Hirano (1983a). We visited the study area almost every other day for 3-4 $\mathrm{h}$ in the morning. A total of $358 \mathrm{~h}$ was spent observing wagtails.

The Tagawa River is $30-50 \mathrm{~m}$ wide. About $90 \%$ of the river is open water, but dead twigs and water vegetation such as Ranunculus and Hydrilla emerge from the water as islets and provide the wagtails with feeding areas. The rest is chiefly gravelly areas. Grasses are found in some places along the bank, which is made of concrete. Beyond the bank are paddy fields, farmland and human habitation.

We recorded the position and behaviour of individual wagtails on a $1: 1500$ scale map as we walked along the river at a speed of about $1.5 \mathrm{~km} / \mathrm{h}$. In addition to this general survey, the number of songs was recorded every 10 minutes for one individual. This was repeated ten times using five to six males every half month to show the seasonal fluctuation of singing activity. Time spent on the river was recorded for periods of $1 \mathrm{~h}$ per individual, and a total of 4-5 h per individual was spent investigating the frequency of use of the river. Flight directions from the nest for collection of food were recorded for two pairs of each species. Those pairs were selected because the environments around their nests were open enough to allow us to observe flight directions. Breeding was monitored in only some of the pairs, whose nests or parental behaviour could be observed well.

Only two $M$. grandis and one $M$. alba lugens ( $M$. alba hereafter for simplicity) were ringed but it was possible to recognize many other individual wagtails by differences in plumage pattern and other morphological features including bill colour and leg injury. Variation in plumage pattern was particularly noticeable in $M$. alba, and all individuals in the study area could be identified at least for one breeding season. In $M$. grandis individual recognition was more difficult. Consequently, individuals observed in particular sections of the river were considered to be the same individuals unless some difference of plumage or behaviour was noted. The sexes were distinguished by plumage pattern in both species. In $M$. grandis the back is darker in males than in females (Yamashina 1933, Higuchi \& Hirano 1983a). In $M$. alba, males have darker head, bib, and back than females (Yamashina 1933, Wild Bird Society of Japan 1982).

The feeding technique of wagtails was classified into the following four categories, as in Higuchi \& Hirano (1983). (1) Ground feeding: feeding on the ground, concrete banks, or house roofs while walking; (2) flycatching I: feeding on insects in the air above the water surface; (3) flycatching II: feeding while fying at the water surface; (4) flycatching III: feeding on insects on the walls of banks and buildings while flying. The frequency of these different feeding techniques was estimated by counting the number of capture attempts for one minute repeated two to four times a day, for each individual.

\section{Results}

\section{Home range and territoriality}

Ten to eleven pairs of $M$. grandis and eight to nine pairs of $M$. alba bred every year during the study period. The home ranges of the two species greatly overlapped and 


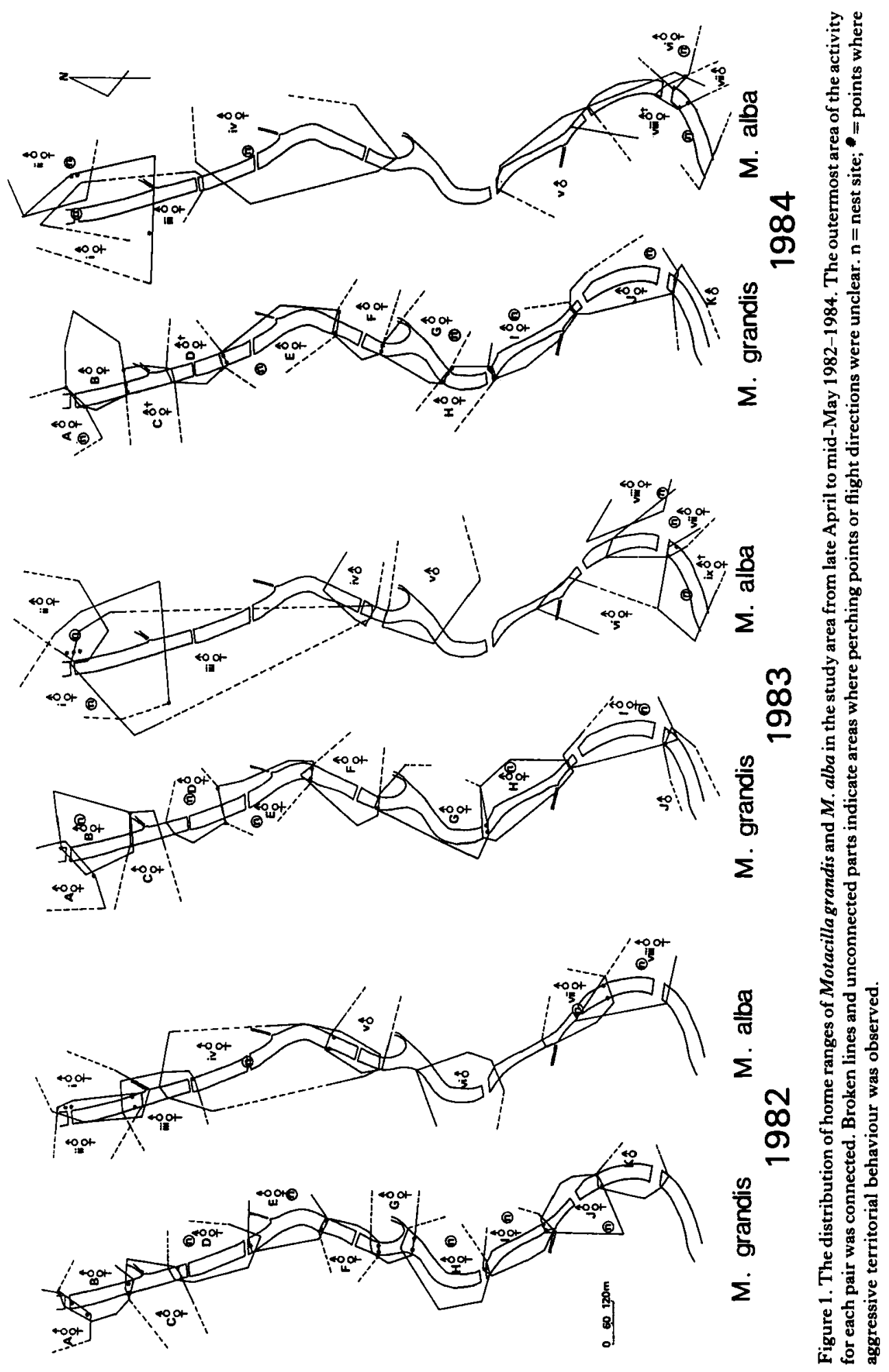


interspecific territoriality was not observed (Fig. 1). No interspecific pairs were formed.

In $M$.grandis, the overlap of home ranges among different pairs was very narrow. Aggressive behaviour of ritualized threat display and physical fights with loud calls 'joy joy jiji---' (Hirano 1981) was observed at the overlapping areas, and a defended area was easily recognized for each pair, particularly on the river. Home range was equivalent to territory in this species. In $M$. alba, on the other hand, many home ranges greatly overlapped among pairs. A few aggressive encounters including ritualized threat display and physical fights with faint calls 'chubi chubi' (Watanabe \& Maruyama 1977) were observed at the overlapping areas but a defended area could not be clearly recognized. Neighbouring or floating males sometimes sang vigorously near the centre of other home ranges (e.g. nest site) when the male owner was absent. The male owner chased the intruders when he found them.

Two cases of forced extra-pair copulation were observed in $M$. alba. In one case in 1983, Female $i x$ (see Fig. 1) was forcibly mounted by an unknown intruder while she was nest-building. In the other case in 1984, Male viii forcibly copulated with neighbouring Female $v i$ that was feeding at the overlapping area of home ranges. Female viii was at the egg-laying stage and Female $v i$ was at the nest-building stage. Forced extra-pair copulation and singing near the nest of other pairs were never observed in $M$. grandis.

\section{Habitat use and nest site}

The time spent on the river was significantly longer in $M$. grandis than in $M$. alba (Table 1, Mann-Whitney $U=0, z=-3.259, n_{1}=6, n_{2}=10, P<0.001$, one-tailed). $M$. grandis spent on an average 28.4 minutes per hour on the river, whereas $M$. alba

Table 1. Time spent by $M$. grandis and $M$. alba on the river

\begin{tabular}{|c|c|c|c|}
\hline \multirow{2}{*}{$\begin{array}{c}\text { Individual } \\
\text { (territory, year, and sex) }\end{array}$} & \multirow{2}{*}{$\begin{array}{c}\text { Hours of } \\
\text { observations }\end{array}$} & \multicolumn{2}{|c|}{$\begin{array}{l}\text { Time (min) spent } \\
\text { on the river per hour }\end{array}$} \\
\hline & & Range & Mean $\pm 8 . d$. \\
\hline \multicolumn{4}{|l|}{ M. grandis } \\
\hline$B, 1983$, male & 5 & $19-49$ & $35 \cdot 6 \pm 11 \cdot 3$ \\
\hline$H, 1983$, male & 5 & $21-39$ & $30 \cdot 6 \pm 6 \cdot 8$ \\
\hline$H, 1983$, female & 2 & $37-42$ & $39 \cdot 5$ \\
\hline 1,1983 , female & 5 & $13-25$ & $16 \cdot 6 \pm 4 \cdot 9$ \\
\hline$F, 1984$, male & 4 & $10-32$ & $22 \cdot 5 \pm 9 \cdot 7$ \\
\hline$I, 1984$, male & 4 & $20-36$ & $25 \cdot 3 \pm 7 \cdot 3$ \\
\hline \multicolumn{4}{|l|}{ M. alba } \\
\hline iv, 1982, male & 5 & $0-2$ & $1 \cdot 2 \pm 1 \cdot 1$ \\
\hline$i, 1983$, male & 5 & $0-5$ & $2 \cdot 6 \pm 2 \cdot 1$ \\
\hline$i, 1983$, female & 4 & $0-4$ & $1 \cdot 8 \pm 2 \cdot 1$ \\
\hline vii, 1983, male & 5 & $0-6$ & $1 \cdot 2 \pm 2 \cdot 7$ \\
\hline vii, 1983 , female & 5 & $0-6$ & $1.8 \pm 2.7$ \\
\hline$i x, 1983$, male & 5 & $0-5$ & $1.6 \pm 2 \cdot 3$ \\
\hline$i x, 1983$, female & 5 & $0-8$ & $5 \cdot 2+3 \cdot 1$ \\
\hline$i, 1984$, male & 2 & 0 & 0 \\
\hline$i, 1984$, female & 2 & $3-11$ & $7 \cdot 0$ \\
\hline iv, 1984 , female & 4 & $0-7$ & $2 \cdot 0 \pm 3 \cdot 4$ \\
\hline
\end{tabular}




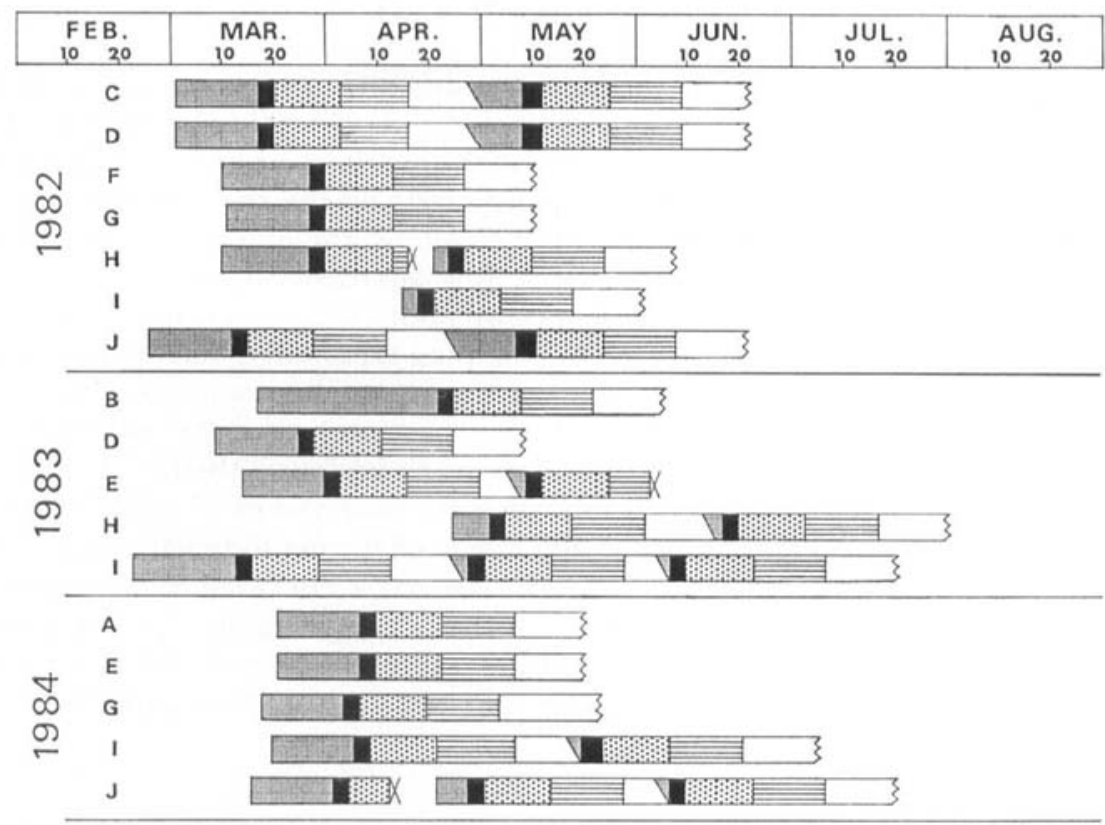

M. grandis

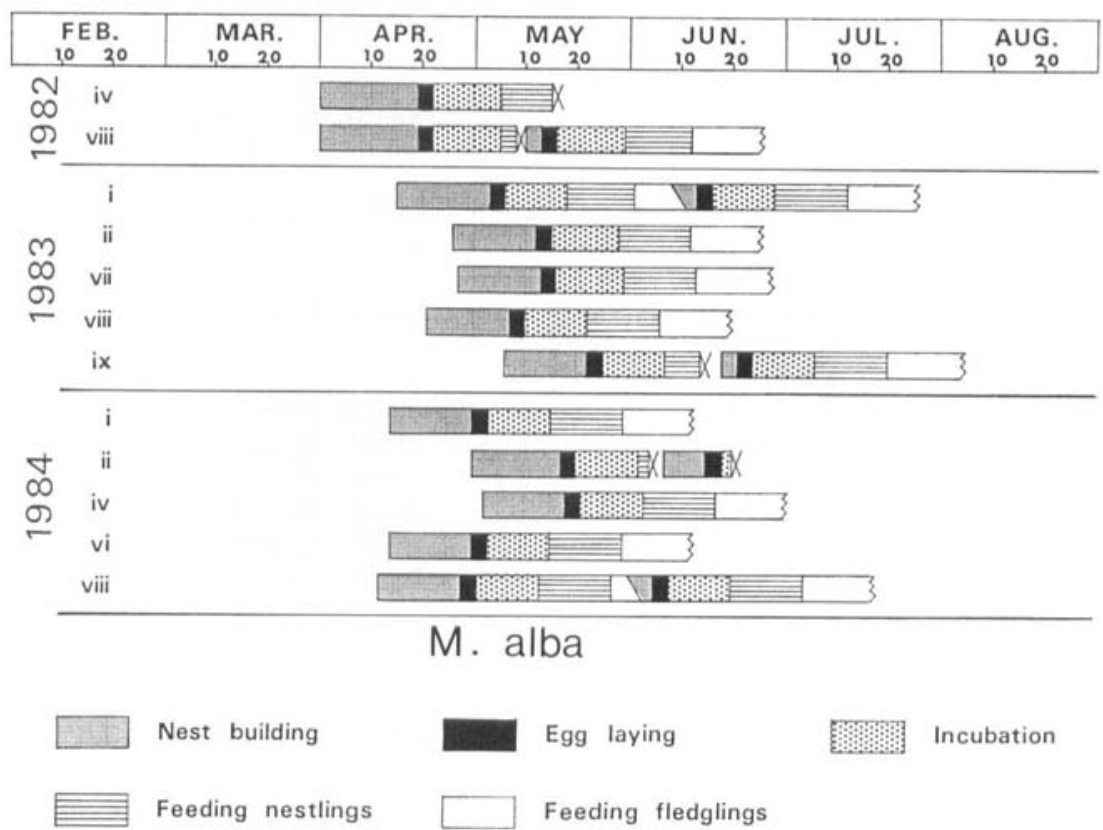

Figure 2. The breeding schedules of $M$. grandis and $M$. alba. The letter next to the year indicates the name of pairs in Fig. 1. $\mathrm{X}$ represents failure at that stage. 
spent only 2.4 minutes. In $M$. alba, the female spent significantly more time on the river than did the male (Mann-Whitney $U=3, z=-1.997, n_{1}=n_{2}=5, P<0.05$, two-tailed). When flying from the nest to collect nestling food, $M$. grandis often went down to the river, while $M$. alba frequently flew away from it.

Nineteen nests of $M$.grandis and 14 nests of $M$. alba were found during the study period. Nest sites were similar in the two species. All of the $M$.grandis nests and 11 of the $M$. alba nests were built in roofs and crevices of buildings. The other three nests of $M$. alba were built in the crevices of bridges. Both species tended to nest along the river, and there was no particular tendency for $M$. alba to nest far away from it.

\section{Breeding season}

The breeding season of $M$.grandis was about $1 \frac{1}{2}$ months earlier than that of $M$. alba (Fig. 2). M. grandis started nesting in late February, and 14 of the 17 pairs that were closely examined laid their eggs between mid-March and early April. In eight of the 17 pairs, the female started a second brood immediately after fledging the first. Pair $I$ of 1983 reared three broods between late February and late July.

In $M$. alba nesting was started in early April, and nine of the 12 pairs laid their eggs in May. Repeat clutches were laid immediately after the failure of the first brood, as in $M$. grandis, but a second brood after a successful first brood was observed only in two pairs of $M$. alba.

\section{Songs and singing activity}

The songs of males were very different between the two species (Fig. 3). In $M$. alba two types of songs were recognized. One is the simple 'chifee' type, which was repeated several times in one sequence. This type of song ( $S i$ type hereafter) was uttered to advertise a male's presence on a conspicuous perch such as a cable or roof, and was used to react to intruders. The other type of song is the complex and whispering 'chichit chichit chuy chuy chuku chuku chi chi chi-----' (Sii type), which was uttered while feeding on the river or on the ground. One phrase of this Sii type song lasted for about 5-15 s. The function of the Sii song was not entirely clear, but it was not used to react to intruders.

In $M$. grandis, there were several song types ranging in complexity from simple 'chujee pitee' to complex 'joy joy ji jiji giji giji giji jijiji juui----', but grouping songs was difficult. These songs were loudly uttered on cables, roofs, and the ground. One phrase of the song lasted for about 2-7 s. Similar but less complex songs were occasionally uttered by neighbouring females on the ground.

Singing started earlier in the season and lasted longer in $M$. grandis than in $M$. alba (Fig. 4). M. grandis started singing in January and sang actively until early April. There was also a small peak of singing activity in early June. $M$. alba sang actively from early March to late April, and the activity was low on both sides of the peak. Both the simple $S i$ and complex $S i i$ type songs were often heard in the peak period, but the seasonal variation tended to be greater in the Si song.

\section{Courtship displays}

Some displays were shown by the male toward the female or vice versa in both species. They include the appeasement display (Hirano 1981 for $M$. grandis, Zahavi 1971 for $M$. alba, Nakamura et al. 1984 for both species) and bill opening display (Hirano 1981 for $M$. grandis).

(a) Bowing display (Fig. 5a). This was observed 11 times only in M. alba males 
(a)

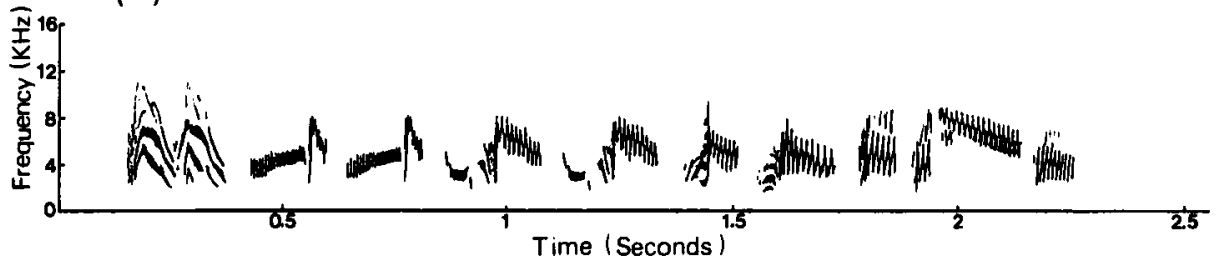

(b)

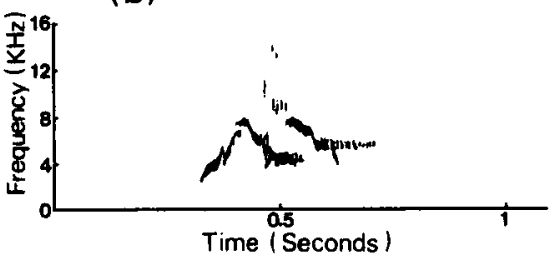

(c)

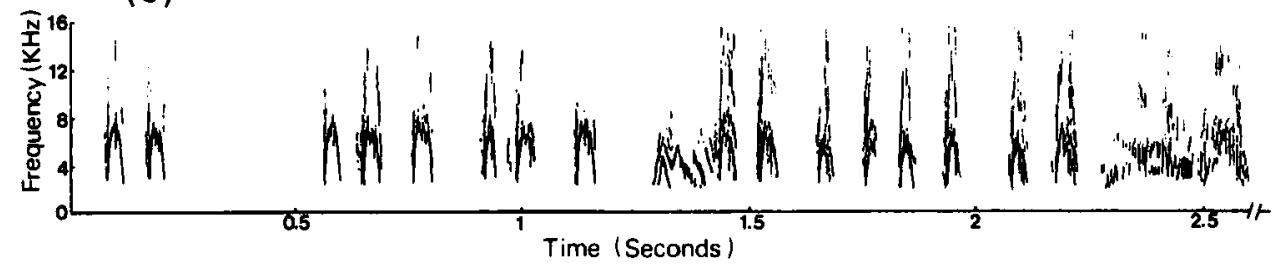

(c) continued
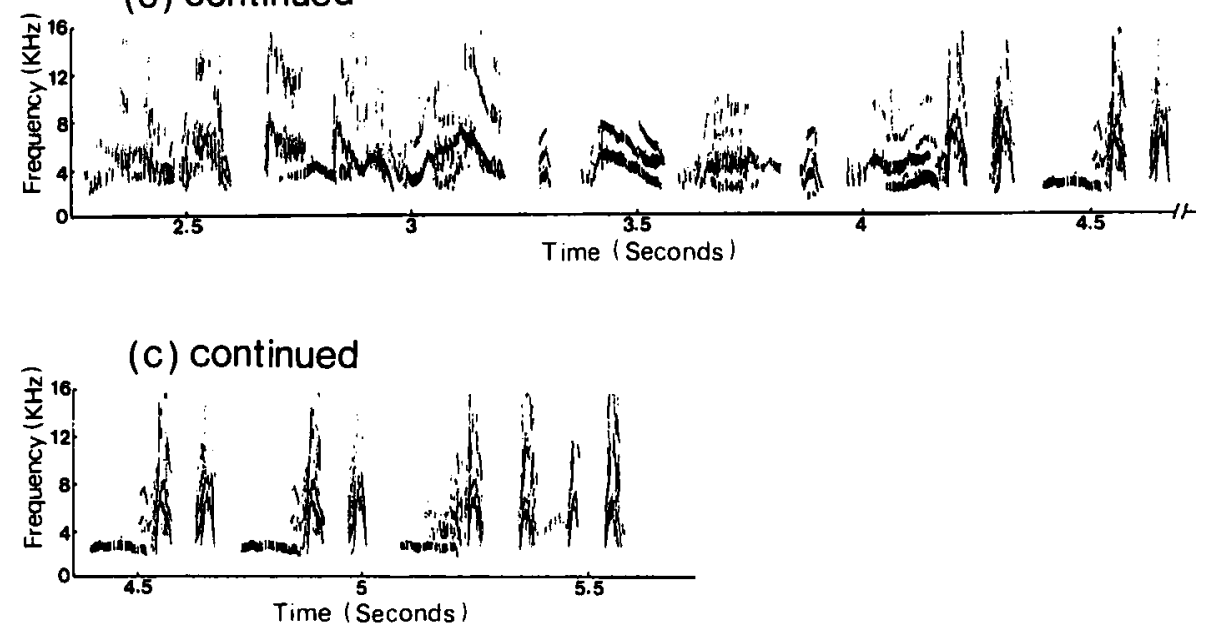

Figure 3. Sonagrams of the song of $M$.grandis (a) and $M$. alba (b and c). (b) stands for a Si type simple song and (c) for a Sii type complex song. 


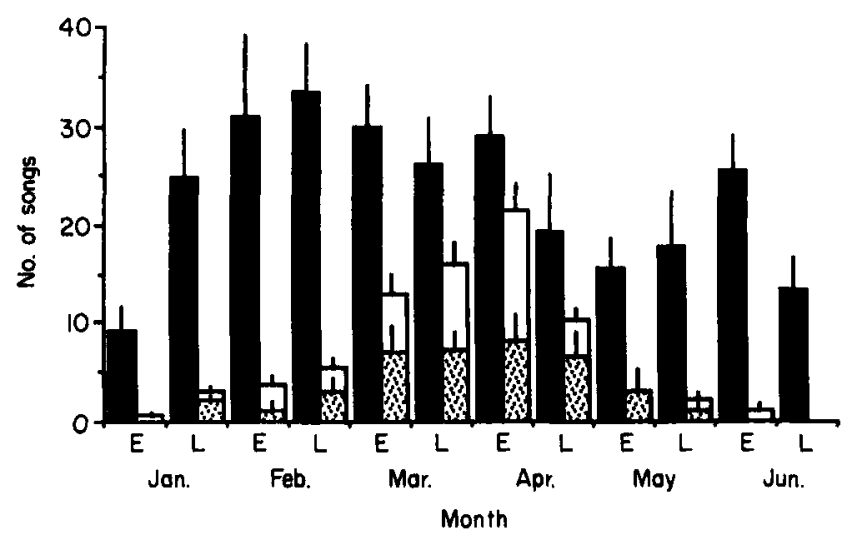

Figure 4. Seasonal fluctuation of the singing activity of $M$.grandis ( $\square$ ) and $M$. alba: Si type song (口) and Sii type (1). Each bar indicates mean number ( + s.e.) of songs per 10 minutes ( $n=10$ every half month). $\mathrm{E}=$ early half of the month; $\mathrm{L}=$ late half of the month. Observations were made in January-June, 1984.

during $358 \mathrm{~h}$ of observation. The male approached the female while moving its head up and down and fluffing its body feathers slightly. When he came within $0 \cdot 5-1 \mathrm{~m}$ of the female, the bowing movement became more active and the wings were quivered. This bowing display was directed not only to his mate but also to other females prior to an attempted forced copulation. The females showed no particular posture to the male. This display usually preceded the pre-copulation display.

(b) Pre-copulation display (Fig. 5b). This was observed between the male and the female 29 times in $M$. grandis and 15 times in $M$. alba. In both species, after flying down to the female $2-3 \mathrm{~m}$ away on hovering wings, the male approached her while lowering his body, fluffing the hip feathers, and opening both his wings and tail. At this moment, the angle of the open wings relative to the horizontal was different for the two species. It was about $40-60$ degrees or sometimes more above the horizontal in $M$. grandis and 10 degrees below in $M$. alba. The posture of the reacting female was similar in both species. Facing the male, the female lowered her body, directed the bill upward, and lifted her tail. This posture was similar to the appeasement display in the two species.

Copulation followed the above behaviour in both species. Bowing and precopulation displays as well as copulation itself were only performed between conspecific individuals.

Table 2. The frequency of the four types of feeding methods in M. grandis and M. alba. See Methods for explanation of the feeding categories

\begin{tabular}{lcc}
\hline & M.grandis & M. alba \\
\hline Total capture attempts observed & 3146 & 995 \\
Frequency of each feeding method (\%) & & \\
$\quad$ ground feeding & 90.5 & 77.4 \\
fycatching I & 6.7 & 13.2 \\
flycatching II & 1.6 & 2.9 \\
fycatching III & 1.2 & 6.5 \\
\hline
\end{tabular}




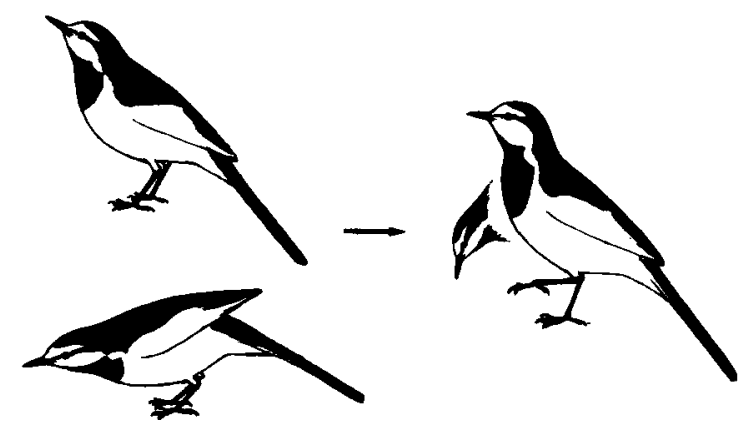

a
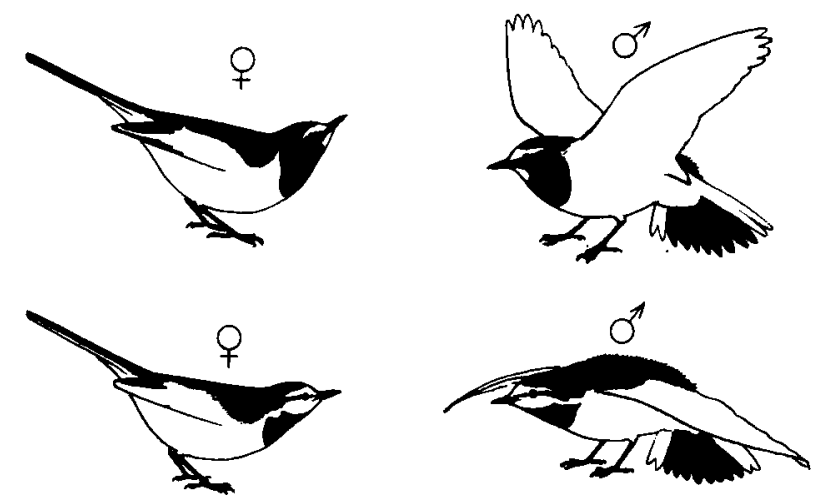

b

Figure 5. Courtship displays in $M$. grandis and $M$. alba. (a) bowing display in male $M$. alba. (b) precopulation display in $M$. grandis (above) and $M$. alba (below).

\section{Feeding habits}

Both species used ground feeding most frequently followed by flycatching I (Table 2 ), but the frequency of feeding methods was significantly different between the two species $\left(G_{3}=126.6, P<0.001\right) . M$. grandis used ground feeding more often and flycatching I, II and III less often than $M$. alba. Both species often took the larvae of mayflies and caddis flies by ground feeding and caught adults by flycatching. $M$. grandis occasionally caught small fish (1-2 cm long) at the water's edge or in shallow water.

Both species used flycatching significantly more often during the breeding season than in winter $\left(G_{1}=160.5\right.$ for $M$. grandis and $G_{1}=160.3$ for $M$. alba, and $P<0.001$ for both species; winter data from Higuchi \& Hirano 1983a). 


\section{Discussion}

M. alba was less dependent on the river than $M$. grandis, having part of its home range away from it. The low dependence on the river in $M$. alba is reflected in their tendency not to have intensively defended territories on the river. $M$.grandis, on the other hand, depends largely on the river, and defends discrete territories there. The same relationship between river dependency and territoriality also applies to the winter ecology of the two species (Higuchi \& Hirano 1983a). Presumably the greater singing activity of $M$. grandis is related to its tendency to defend discrete territories.

Breeding and the related singing activity started much earlier in $M$. grandis than in $M$. alba, and this is associated with other differences in their life history. First, unlike $\boldsymbol{M}$. alba, $\boldsymbol{M}$. grandis does not moult into summer plumage in early spring (pers. obs. and Y. Osako pers. comm., contra Yamashina 1933). Without moulting, $M$. grandis can begin to breed earlier in spring. Secondly, $M$. grandis live in pairs during the winter (Higuchi \& Hirano 1983a), and they can save time in pair formation, though some of the winter pairs are known to change mates in spring (Hirano 1981). M. alba tend to live singly or to form temporary pairs in winter (Higuchi \& Hirano 1983a), and they are more migratory than $M$.grandis (H. Higuchi unpubl.).

Thirdly, it is likely that $M$. alba, which uses flycatching more often, depends more on adult insects (mostly mayflies and caddis flies) than $M$. grandis which feeds on the larvae. Moreover, $M$. alba often went to concrete buildings to collect nestling food, which may have been adult insects fallen to the floor or perching on the wall. The seasonal difference in the availability of adult and larval insects may cause the difference in the breeding season between the two species.

These two species did not interbreed even though their home ranges overlapped to a great extent. The differences in songs, courtship displays, and breeding season may be major isolating mechanisms between them. However, in both species courtship displays were only directed at conspecifics, and no attention was paid to the songs of the other. We did not find any evidence that interbreeding was prevented by differences in songs or courtship display. Species recognition was evident even before the beginning of the breeding season and the members of each species apparently recognize conspecifics during the winter. For example, in both species appeasement display is shown by the female only toward conspecific males (Higuchi \& Hirano 1983a, Hirano \& Higuchi 1986). Dominance rank on the river is strictly determined by the species and sex of an individual (Hirano \& Higuchi 1986). The two species tend to form separate roosting flocks (H. Hirano unpubl.), and the winter pairs that are formed by many $M$. grandis and some $M$. alba are always composed of conspecifics (Higuchi \& Hirano 1983a). While differences in songs and courtship displays between the two species may have played an important role in the speciation process, such differences do not now directly function as isolating mechanisms.

From the description provided by Ali \& Ripley (1973) of $M$. maderaspatensis in India, the pre-copulation display of the male is more similar to that of $M$. grandis than to that of $M$. alba. Namely, the male $M$. maderaspatensis does not droop both wings as does $M$. alba, but lifts its wings upward (vertically in this species) as does $M$. grandis. This similarity in courtship behaviour may be interpreted as evidence for a close relationship between $M$. grandis and $M$. maderaspatensis (Nakamura 1985). However, in order to clarify the relationship we need to know about courtship displays in other subspecies of $\boldsymbol{M}$. alba. Although information is fragmentary, it has been reported that $M$. alba yarrellii in England (Witherby et al. 1938), M. a. personata in central Asia (Dement'ev \& Gladkov 1970), and M. a. alboides in 
southern Asia (Ali \& Ripley 1973) have similar pre-copulation displays to that of our $M$. alba lugens in Japan.

We thank Koichi Endo, Kosuke Nihei, and Isao Tezuka for their assistance in our field work, Hirohiko Sano and Hiroshi Momose for preparing some figures, and Yoshito Osako for providing information on moulting. We are also indebted to Robert B. Payne and Geoffrey E. Hill for commenting on the draft of this paper. This work was supported in part by a grant-in-aid for the Special Research Project on the Biological Aspects of Optimal Strategy and Social Structure from the Japan Ministry of Education, Science, and Culture (Nos. 59215002 and 60107002).

\section{References}

Ali, S. \& Ripley, S.D. 1973. Handbook of the Birds of India and Pakistan. Vol. 9. Oxford: Oxford University Press.

Chen, Tso-Hsin. 1976. A Distributional List of Chinese Birds. 2nd edition. Peiping: Science Publishing House. (In Chinese.)

Dement'ev, G.P. \& Gladkov, N.A. (eds). 1970. Birds of the Soviet Union, Vol. 5. Jerusalem: Israel Program for Scientific Translations.

Higuchi, H. 1984. The world of pied wagtails. Yacho 49: 32-35. (In Japanese.)

Higuchi, H. 1987. The nature and birds of Japan. Yacho 52: 16-21. (In Japanese.)

Higuchi, H. \& Hirano, T. 1981. Breeding records and breeding habitats of the White Wagtail Motacilla alba in Tochigi prefecture. Tori 29: 121-128. (In Japanese with English summary.)

Higuchi, H. \& Hirano, T. 1983a. Comparative ecology of White and Japanese Wagtails, Motacilla alba and $M$. grandis, in winter. Tori 32: 1-11.

Higuchi, H. \& Hirano, T. 1983b. Aberrant plumage of the Japanese Wagtail Motacilla grandis. Strix 2: 76-84. (In Japanese with English summary.)

Hirano, T. \& Higuchi, H. 1986. Dominance hierarchy among wagtail and pipit species living along streams. Jap. J. Ornithol. 35: 79-80. (In Japanese with English summary.)

Hirano, T. 1981. Territory and pair duration of the Japanese Wagtail Motacilla grandis. Tori 30: 23-36. (In Japanese with English summary.)

Koshihara, M. 1983. Breeding records of Motacilla alba lugens and M. a. leucopsis in Omachi, Nagano Prefecture. Tori 32: 176. (In Japanese.)

MAYr, E. 1963. Animal Species and Evolution. Cambridge, Mass.: Harvard University Press.

NakamuRA, K. 1978. Expansion of the breeding distribution of Motacilla alba in Honshu and a preliminary consideration of its cause. Bull. Mus. Soc. Kanagawa. 38: 1-10. (In Japanese with English summary.)

NAKAMURA, K. 1985. Historical change of the geographical distribution of two closely related species of the genus Motacilla in the Japanese Archipelago: a preliminary note. Bull. Kanagawa Prefec. Mus. (Nat. Sci.) 16: 23-36. (In Japanese with English summary.)

NakamURA, K. \& Iwamoto, S. 1985. On the hybrid between Kamtschatkan White Wagtail, Motacilla alba lugens and Japanese Wagtail, $M$. grandis. Nat. Hist. Rep. Kanagawa 6: 41-45. (In Japanese with English summary.)

Nakamura, S., Hashimoto, H. \& Sootome, O. 1984. Breeding ecology of Motacilla alba and M, grandis and their interspecific relationship. J. Yamashina Inst. Ornith. 16: 114-135.

Окаулма, H. 1984. Interbreeding between different subspecies of the White Wagtail Motacilla alba. Tori To Shizen 35: 1-4. (In Japanese.)

Stepanyan, L.S. 1978. Composition and Distribution of Birds of the USSR. Passeriformes. Moscow: Nauka. (In Russian.)

StePanyan, L.S. 1983. Superspecies and sibling species in avifauna of the USSR. Moscow: Nauka. (In Russian.)

Watanabe, M. \& Maruyama, N. 1977. Wintering ecology of White Wagtail Motacilla alba lugens in the middle stream of Tama River. Misc. Rep. Yamashina Inst. Orn. 9: 20-43.

Wild Bird Society of JAPAN. 1982. A Field Guide to the Birds of Japan. Tokyo: Wild Bird Society of Japan.

Witherby, H.F., Jourdain, F.C.R., Ticehurst, N.F. \& Tucker, B.W. 1938. The Handbook of British Birds, Vol. 1. London: Witherby.

Yamashina, Y. 1933. A Natural History of Japanese Birds, Vol. 1. Tokyo: Azusa-shobo. (In Japanese.)

ZAHAVI, A. 1971. The social behaviour of the White Wagtail Motacilla alba alba wintering in Israel. Ibis 113: 203-211. 